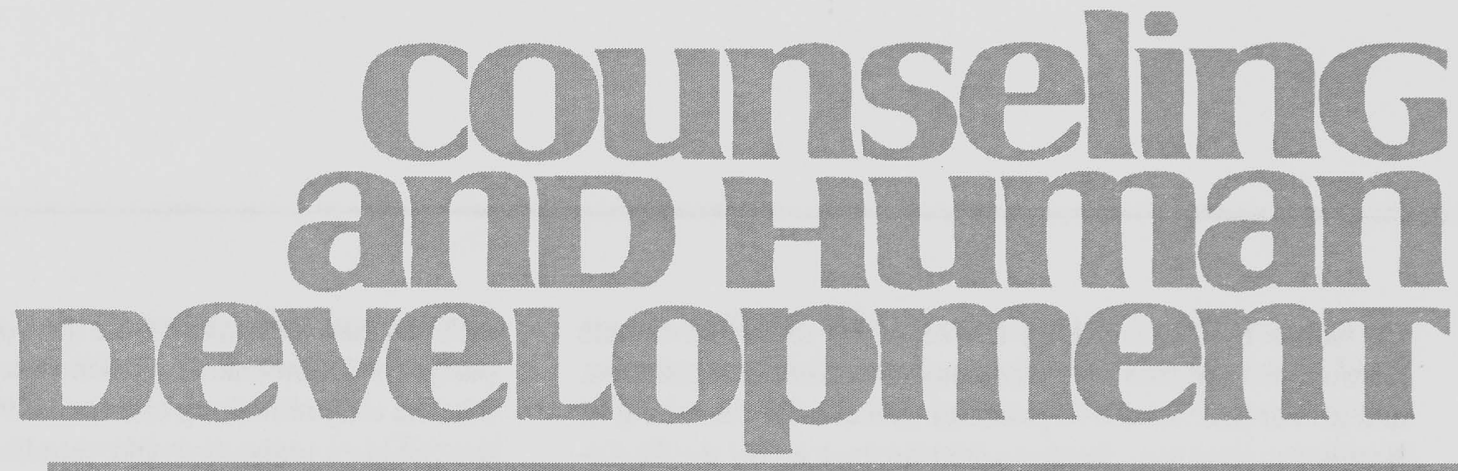

\title{
What Counselors Need to Know About Health Care Reform
}

\author{
Scott Barstow
}

"Of all the forms of inequality, injustice in health care is the most shocking and inhumane." -Dr. Martin Luther King, Jr.

'Millions of our citizens do not now have a full measure of opportunity to achieve and enjoy good health. Millions do not now have protection or security against the economic effects of sickness. The time has arrived for action to help them attain the opportunity and that protection.'

—President Harry S. Truman, letter to Congress, November 19, 1945

More than 60 years after President Truman wrote those words and nearly 100 years since health insurance was proposed by Teddy Roosevelt, the United States has joined the rest of the developed nations in initiating a health care system aimed at establishing universal insurance coverage. President Barack Obama and his colleagues in the House and Senate succeeded where many, many others failed, but just barely. The legislation, described as "similar in scope to Great Society and New Deal programs," was enacted "without the benefit of the congressional majorities of those eras" (Oberlander, 2010). For some health care advocates, the law was a disappointment, as it missed opportunity to establish a "public option" for health insurance, a publicly financed and operated program similar to Medicare to provide broad coverage. For others, the legislation constituted the transformation of the United States into a socialist state, somehow endangering America's "freedoms." The reality is that the new law keeps the predominant role of private insurance coverage and welds it to a new framework of rules, investments in improving the effectiveness and efficiency of care, and a strengthened public health sector to establish a more rational system. The law will have a significant impact on counselors as both consumers and providers of health care services, and its enactment has implications for counselor advocacy.

\section{HOW THE LEGISLATION WAS PASSED}

The first floor vote in Congress was in the House of Representatives, where on November 7, 2009, the chamber passed its version of health reform legislation (H.R. 3962, the "Affordable Health Care for America Act") by a vote of 220-215. The Senate went next, passing its version (H.R. 3590, the "Patient Protection and Affordable Care Act") on

Mr. Barstow is the Director of Public Policy and Legislation for the American Counseling Association. 
Christmas Eve morning by a vote of 60 to 39; all Senate Democrats (and two Independents) voted for the legislation, and all but one Senate Republican (Senator Jim Bunning of Kentucky, who was absent) voted against it. By the beginning of 2010, House and Senate members and their staffs were working to bridge the differences between the two bills, which shared a similar, evolutionary approach to upgrading the nation's health care system.

Then a bump in the road occurred, when on January 19, 2010, Republican Scott Brown won the special election in Massachusetts to fill the vacant Senate seat of the late Senator Edward Kennedy. For decades, Senator Kennedy had been the institution's leading champion for health care access, and it appeared for a time that his death in August and Brown's victory in January might spell the end of this most recent attempt at health care reform. Although Paul Kirk, the person appointed to fill Kennedy's seat until the special election, voted in favor of the health care reform bill on Christmas eve, the newly installed Senator Brown became a 41 st vote against it. This created a barrier to passage of a House-Senate conference proposal in the Senate, due to procedural rules which typically require 60 votes in

\section{counseling and Human Development}

ISSN 0193-7375

COUNSELING AND HUMAN DEVELOPMENT (USPS 203-420) is published monthly except June, July, and August as a service to counseling and human services professionals in schools, agencies, mental health centers, higher education, business and industry, and other private settings. This journal is available in microfilm from Serials Acquisitions, National Archive Publishing Company, P.O. Box 998, Ann Arbor, MI 48106-0998. Subscription rates: individual, \$48 per year; institutions, \$66 per year. Copyright @ C 2010, Love Publishing Company. All rights reserved. Reproduction in whole or part without written permission is prohibited. Printed in the United States of America. Periodical postage is paid at Denver, Colorado. POSTMASTER: Send address changes to:

Love Publishing Company

Executive and Editorial Office P.O. Box 22353

Denver, Colorado 80222

Telephone (303) 221-7333

Mark Kiselica

The College of New Jersey
Paul Peluso Florida Atlantic University

Rita Chi-Ying Chung

George Mason University-Fairfax

Stanley F. Love

Publisher
Carrie E. Watterson Senior Editor order to pass legislation over the opposition of the minority party; the Democrats (and two Independents) were stuck at 59. The only remaining alternative was for the House to pass the Senate's legislation and simultaneously adopt a limited set of changes to the Senate's bill using budget reconciliation procedures. Under congressional rules of procedure, budget reconciliation legislation (to "reconcile" federal spending and programs with the budget approved for the year by Congress) requires only a 51-vote majority to pass in the Senate. Given the frequent use of legislative roadblocks and filibuster threats by the minority party in the Senate, the budget reconciliation process has been used frequently - by both parties - to consider major legislation.

Throughout health care consideration, Republicans demonstrated near-total party control over their caucus members on the issue and fought against the legislation vigorously. Only one Republican House member, Rep. Anh "Joseph" Cao, from Louisiana, voted for the legislation when it was initially passed in November of 2009, and not a single Republican voted for the final version of the legislation in either the House or Senate. Republican Senator Jim DeMint, from South Carolina, told advocates on a conference call in July of 2009 that "this health care issue is D-Day for freedom in America," and that, "if we're able to stop Obama on this it will be his Waterloo. It will break him" (Smith, 2009).

The closest congressional Republicans came to putting forward their own proposal was legislation drafted by House Minority Leader John Boehner (R-OH) and offered as an amendment on the House floor during floor consideration of health care on November 7th. According to the analysis of Boehner's legislation conducted by the Congressional Budget Office (CBO) and the Joint Committee on Taxation (JCT), it would have helped only 3 million Americans gain health insurance by 2019-roughly matching the expected increase in population over that time period,--leaving 52 million Americans without insurance. As noted by the $\mathrm{CBO}$ and JCT in their analysis, Boehner's legislation would leave the percentage of US nonelderly legal residents without health insurance unchanged, at $17 \%$, the same as under current law (CBO, 2009a). Although Republicans had earlier attacked the Democrats' legislation for its effect on the federal deficit, the Boehner legislation was projected by $\mathrm{CBO}$ to reduce the deficit by only $\$ 68$ billion over 10 years, as compared to the $\$ 109$ billion deficit reduction the $\mathrm{CBO}$ projected for the Democrats' bill (CBO, 2009a; CBO, 2009b).

The $\mathrm{CBO}$ analysis concluded that Boehner's legislation would reduce insurance premiums for some individuals, in part because of its inclusion of medical malpractice reform provisions as well as the elimination of state insurance benefit mandates. However, Republicans' commitment to voting against the overall package gave Democratic leaders no reason to consider including major malpractice reform provisions in the final legislation. During health care legislation's 
consideration by three House committees and two committees in the Senate, a grand total of one Republican, Senator Olympia Snowe (R-ME), voted for the Senate Finance Committee legislation. Senator Max Baucus (D-MT) tried for months during the summer of 2009 to put together a bipartisan health care reform bill, working with a group of two Democratic and three Republican members of his Senate Finance Committee. Ultimately, Snowe was the only Republican supporter. Baucus's work with Senators Snowe, Mike Enzi (R-WY), Charles Grassley (R-IA), Kent Conrad (D-ND), and Jeff Bingaman (D-NM) to hammer out a plan delayed consideration of health care reform well beyond deadlines suggested earlier in the year by the president. Senator Snowe voted against health care reform when it reached the Senate floor.

At bottom, a key irreconcilable difference separated the two political parties: Democrats were committed to significantly expanding insurance coverage, while Republicans were concerned almost exclusively with reducing the cost of care. Added to this was the divide between the two parties' perception of the proper role of government, with Democrats convinced that the private sector could not be entrusted with covering substantially all Americans at low cost, and Republicans convinced that, as Henry David Thoreau stated, "That government is best which governs least." Each party managed to develop legislation that achieved its goals. The $\mathrm{CBO}$ projected that the Patient Protection and Affordable Care Act (PPACA) will bring health insurance coverage to an additional 32 million Americans and also projected that Congressman Boehner's draft legislation would slightly reduce health insurance premiums, even if it did not expand coverage noticeably.

If health care reform was going to pass, it would do so with only Democrats' votes, and after weeks of intense negotiations, it did. On March 21st, House Speaker Nancy Pelosi (D-CA) accomplished what many had considered the impossible, convincing a strong majority of her fellow Democrats from all separate wings of the party to vote for a health care bill that many found wanting; some Democrats thought it was too expensive, others were concerned about its potential to restrict access to abortion further than under current law, and others had pushed to include a public health care option and were reluctant to vote for legislation without it. The House vote on the bill was 219-212, and the package of minor amendments to the legislation was approved by a similar 220-211 vote. The Senate approved the changes by a 56-43 vote, and on March 23rd President Obama signed the health care reform legislation into law.

The Patient Protection and Affordable Care Act of 2010 (PPACA) "ranks alongside the most important pieces of social policy legislation in recent American history, including the Social Security Act (1935) and the Civil Rights Act (1964)" (Morone, 2010, p. 1096), and it is considered "the most significant law for people with disabilities since the enactment of the Americans with Disabilities Act (ADA)" (The Arc, 2010). Counselors concerned about social justice are likely to view enactment of health care reform law as cause for celebration, as it likely constitutes "the federal government's biggest attack on economic inequality since inequality began rising more than three decades ago" (Leonhardt, 2010).

More importantly, the law will save lives. A study by Andrew Wilper of Harvard Medical School estimated that as many as 44,000 deaths per year in the United States are associated with a lack of health insurance, more than the number of annual deaths caused by kidney disease (Wilper et al., 2009). Wilper and his colleagues found an increased hazard ratio for individuals without insurance, after controlling for gender, age, race/ethnicity, income, education, current unemployment, smoking status, regular alcohol use, self-rated health, physician-rated health, and body mass index. Even if this figure significantly overestimates mortality caused by lack of coverage, Dr. King's characterization of inequal access to care as "inhumane" is all too accurate.

The public debate over the legislation was filled with acrimony, demagoguery, blatant mischaracterizations, and more heat than light. Sadly, members of Congress and their families were even subjected to death threats over the legislation (Nasaw, 2010). During House floor debate on passage of the measure, which occurred on March 21, 2010, Rep. Kathy McMorris Rodgers (R-WA) said the bill would "cripple free enterprise and permanently diminish the freedom of the American individual." (Congressional Record, March 21, 2010, p. H1887). Rep. John Campbell (R-CA) was quoted by the newspaper The Hill as saying passage of the health care bill would be "the beginning of the end of America." Unfortunately for counselors, this highly charged environment and the disinformation spread about the bill contributed to the loss of an opportunity to gain Medicare reimbursement.

Given the necessarily incremental nature of the legislation and the complexity and difficulty of the issues it attempts to address, battles over health care reform are far from over. This has happened before; as Theda Skocpol has noted, the Social Security program underwent significant changes and interruptions after it was established in 1935 and was not solidly supported until the 1960s and 1970s (Skocpol, 2010). The PPACA's provisions phase in over time, and conservative advocates have made it clear they want to repeal the law in any way they can. If the promise of health security for all Americans is to be achieved, it is important for counselors to know how the bill affects them in order to engage responsibly with policymakers both as members of an interest group and as members of the voting public, in addition to their more direct roles as consumers or providers of care. 


\section{TWIN GOALS: COVERAGE AND COST REDUCTION}

The two basic goals of PPACA are to substantially increase health insurance coverage and constrain the growth in health care spending. Neither goal is achievable without addressing the other: Unless the cost of health care stops rapidly increasing, providing insurance to those without it will become unaffordable; with millions of Americans left out of the system, those with insurance will be hit with ever steeper premium hikes to cover the cost of uncompensated care. An even more fundamental driver of health care reform is the federal deficit. Without reform, Medicare and Medicaid spending would rise inexorably, making it almost impossible to control the federal deficit, as shown in Figure 1. Although change is never easy, changing our health care system is a fiscal necessity. According to the CBO, the PPACA will reduce the federal deficit by $\$ 143$ billion over the 2010-2019 time period (CBO, 2010). The Medicare Board of Trustees recently projected that the Medicare Part A Hospital Trust Fund would be solvent through 2029, an extension of 12 years from the estimate they made last year, as a result of the savings achieved in the Act.
The United States is spending twice as much per capita on health care as all other developed nations, and we are getting significantly worse outcomes in return. Figure 2 should reassure even the biggest skeptic that we can do better. Indeed, those who opposed (and continue to oppose) the PPACA because it would "break the bank" ignore the fact that our long-standing lack of a decent health care system has been doing so already for some time. Figure 1 shows that with the health care system we had in 2009, not only would Medicare and Medicaid spending rapidly eat up more and more of federal and state budgets, but private health insurance and personal out-of-pocket expenditures would rise inexorably as well. Figure 2 shows that while we have been spending roughly twice what most other developed countries do on health care, we are not getting any better outcomes for it. Startlingly, life expectancy for a US citizen is about the same as for a resident of Cuba, while Cuba spends less than a tenth as much per capita on care.

The PPACA is both evolutionary (instead of revolutionary) and comprehensive. The Act takes the pieces of our current patchwork of private, federal, and state health programs and

\section{Relative Contributions to NHE By Source of Funds, 1999 to 2019 (in Billions)}

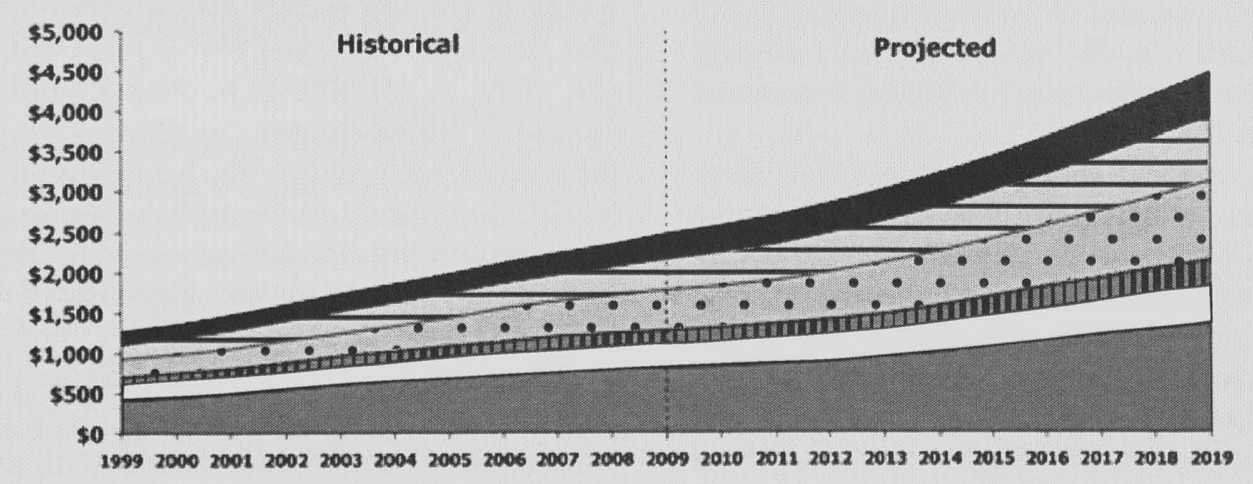

\begin{tabular}{|lll|}
\hline DPrivate Health Insurance & $\square$ Out of Pocket & DO Other Private \\
$\square$ Medicare & $\square$ Medicaid & Other Public \\
\hline
\end{tabular}

Note: First profected year is 2009.

Source: Centers for Medcare and Medicau Services, Oflice of the Actuary. National Heath Stetistics Group, at

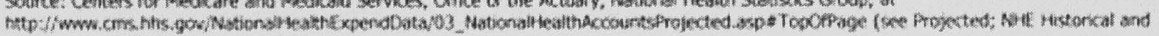
projections, 1965. 2019, fie nhes 5-19.2p).

Source: From National Health Expenditure Data, by the Centers for Medicare and Medicaid Services, Office of the Actuary, National Health Statistics Group, 2010. Retrieved from http://facts.kff.org/chart.aspx?ch=858, and modified for readability in black and white printing. 


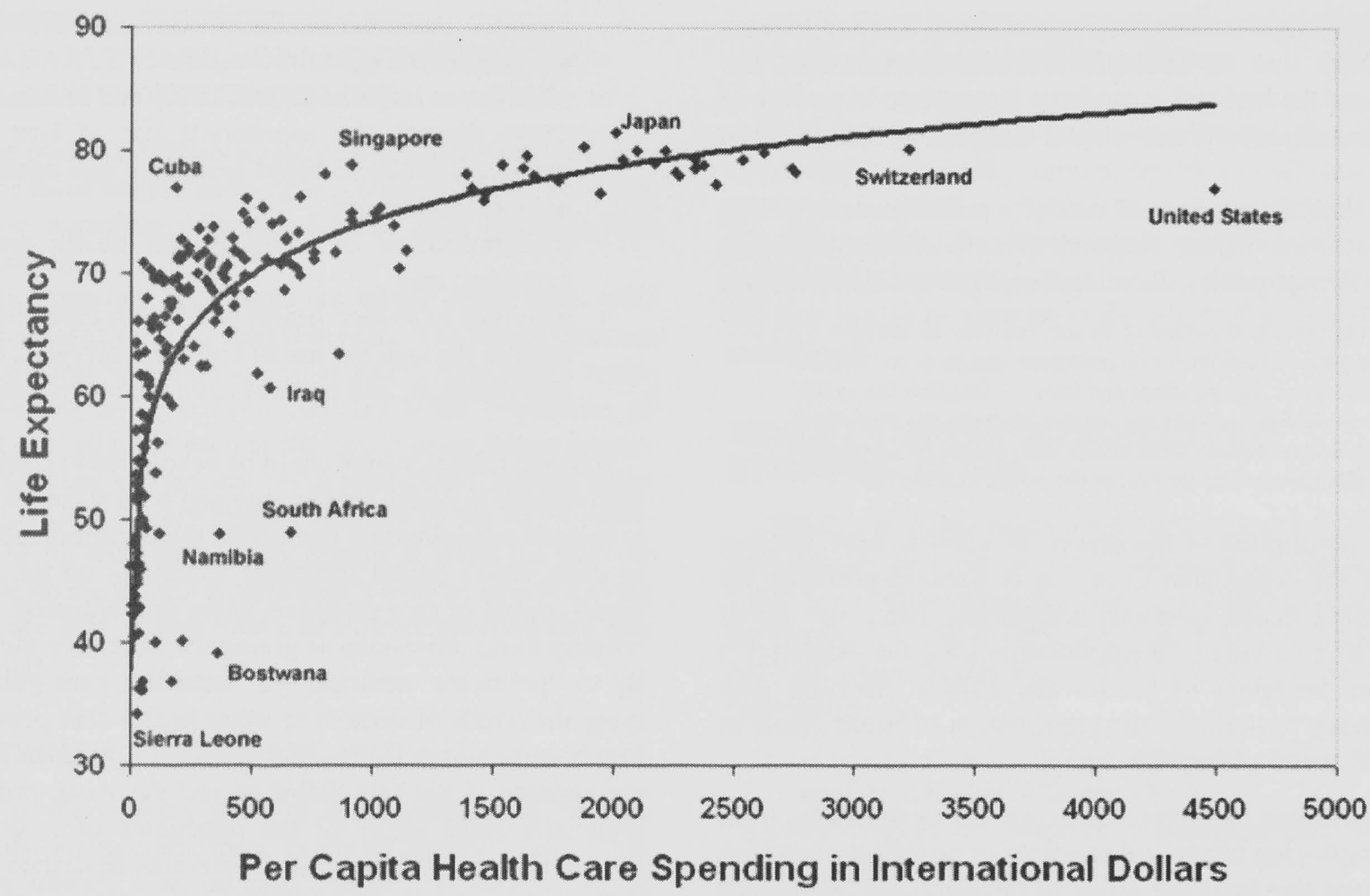

Source: From UC Atlas of Global Inequality, by the University of California at Santa Cruz, Center for Global, International, and Regional Studies. Retrieved from http://ucatlas.ucsc.edu/index.php. Reprinted with permission.

\section{FIGURE 2. International Comparison of Life Expectancy v. Per Capita Spending - Year 2000}

attempts to iron them out and make the seams match up better. Near universal health insurance coverage will be achieved through a combination of expanding Medicaid and subsidizing (and requiring) the purchase of health insurance by those who previously went without it. Private sector health plans will be forced to compete on how well they provide health care services, not on how well they can attract healthy enrollees and avoid unhealthy ones. In return, they will get millions of new customers. States will set up new insurance pools for individuals and small businesses to get coverage. To help hold down costs, the Act establishes an array of incentives, programs, and new funding to improve efficiency; foster the development of new service delivery structures and payment mechanisms; and combat waste, fraud, and abuse.

Like all major pieces of legislation, the Act is divided into several titles, or major sections. Title I of the Act includes provisions establishing private insurance plan protections, health insurance exchanges, and insurance subsidies, and delineating individual and employer responsibilities. Title II of the Act makes changes to streamline and expand the Medicaid program. Title III contains provisions to foster the development of new patient care models and purchasing systems and to make improvements in Medicare, including in prescription drug coverage. Title IV establishes programs aimed at preventing chronic disease and improving public health, by improving coverage of preventive services, promoting wellness, and increasing funding for communitybased programs and services. Title $\mathrm{V}$ contains provisions designed to strengthen the health care workforce, primarily in order to improve the delivery of health care services for low-income, rural, underserved, and minority populations. Title VI of the Act includes measures aimed at improving the transparency of the health care system and combating waste and fraud. Title VII of the Act seeks to increase competition and innovation in biologically based therapies. Title VIII of the Act contains the Community Living Assistance Services and Supports (CLASS) Act, to establish a national voluntary insurance program for purchasing long-term care. Finally, Title IX of the Act includes the tax- and revenuerelated provisions necessary to pay for the insurance subsidies and programs it includes.

The discussion that follows is by no means exhaustive; instead, it describes only the basics of the law. Much information about the law and its implementation is available 
online (and more will be coming) for those wanting to learn more. Now that the firestorm over its consideration has passed and the legislation has been signed into law, some of the misinformation about what it does has abated. But not much.

The Wall Street Journal recently published an opinion piece-entitled "Dear Patients: Vote to Repeal Obama Care"-by a physician claiming that Section 1311 of the law

gives the US Secretary of Health and Human Services ... the power to establish care guidelines that your doctor must abide by or face penalties and fines.... This new law politicizes medicine and in my opinion destroys the sanctity of the doctor-patient relationship that makes the American health care system the best in the world. (Scherz, 2010)

This description of the law is, in a word, false. Section 1311 of the Affordable Care Act is focused primarily on establishing health insurance exchanges. Paragraph (c) of this section (entitled "Responsibilities of the Secretary") tasks the Secretary of Health and Human Services with establishing "criteria for the certification of health plans as qualified health plans," including:

- marketing requirements to prevent health plans from employing marketing practices or benefit package designs that have the effect of discouraging individuals with significant health needs from enrolling in the plan;

- ensuring sufficient choice of providers, including essential community providers serving predominately low-income, medically-underserved individuals;

- being accredited "with respect to local performance on clinical quality measures such as the Healthcare Effectiveness Data and Information Set, patient experience ratings on a standardized Consumer Assessment of Healthcare Providers and Systems survey, as well as consumer access, utilization management, quality assurance, provider credentialing, complaints and appeals, network adequacy and access, and patient information programs by an entity recognized by the Secretary";

- implementing a quality improvement strategy and reporting annually on pediatric quality measures; and

- utilizing a uniform enrollment form for qualified individuals and employers.

Paragraph (g) of Section 1311 (entitled "Rewarding Quality Through Market-Based Incentives") calls on the Secretary to develop guidelines for the development and use of payment structures to reward high quality, cost effective care, such as through:

- implementation of effective case management, care coordination, chronic disease management, and medication and care compliance initiatives;

- activities to prevent hospital readmissions through a comprehensive program for hospital discharge that includes patient-centered education and counseling and post-discharge reinforcement;

- activities to improve patient safety and reduce medical errors through the appropriate use of best clinical practices, evidence based medicine, and health information technology;

- implementation of wellness and health promotion activities; and

- activities to reduce health and health care disparities, such as through the use of language services, community outreach, and cultural competency training.

The guidelines, which are to be developed in consultation with experts in health care quality and with stakeholders, are to include a requirement that health plans periodically report to their state's health insurance exchange on the marketbased quality of care strategies being implemented. Characterizing these provisions as giving the Secretary the authority to "politicize medicine" or "establish care guidelines" tying the hands of doctors or other health care providers is highly misleading. It is easy to imagine opponents expressing outrage if the law failed to include these provisions, especially since many of the opponents of reform have argued fiercely that the kinds of services described in paragraph $(\mathrm{g})$ are worth spending billions of dollars of taxpayers' money on when provided by Medicare Advantage managed care plans.

Such pieces prove that many Americans remain adamantly opposed to extending access to health insurance coverage to their neighbors. Sadly, Americans appear to be growing more, not less, ignorant regarding the Act. A survey conducted by the Associated Press found that $81 \%$ of those surveyed believed the Act would increase the federal government's debt, when in fact the law is projected by the CBO to reduce government spending by billions of dollars (Alonso-Zaldivar \& Tompson, 2010). This author received a chain email at the beginning of September which castigated members of Congress for "exempting themselves" from the new health care law (among other false reasons) and implored the reader to throw the bums out, using a constitutional convention, if necessary. Angry, ignorant emails are constantly flying around the internet, but this one is particularly frustrating because the PPACA is very clear on this issue: Members of Congress and congressional staff must get health insurance coverage through one of the new health insurance exchanges.

The PPACA creates the blueprint, but it will take a few years to build the system the law spells out. The construction process will require ongoing political decision making; the more this process is based on facts instead of myths, the better our collective outcome will be. An understanding of the law is best achieved through the use and comparison of multiple reliable sources and comparing descriptions, analyses, summaries, and the text of the law itself. ${ }^{\prime}$ 


\section{THE PATIENT PROTECTION AND AFFORDABLE CARE ACT AND COUNSELORS AS HEALTH CARE CONSUMERS}

Since most Americans already have private health insurance, the most widely applicable provisions of the new law are those regarding private insurance plan practices and requirements.

Many important provisions are taking effect now, with more happening over the next few years. The largest changes will take effect in 2014, the year in which state health insurance exchanges begin operation, but some provisions of PPACA take effect in each of the next 5 years. Many important protections are already being established, having taken effect this year. A very helpful timeline of the Act's provisions-along with many other resources about the law-is available on the federal government's website devoted to the health care law, at http://www.healthcare.gov/law/timeline/ index.html.

\section{GRANDFATHERED HEALTH PLANS}

One of the primary goals of the legislation is, to paraphrase the Hippocratic oath, to do no harm to individuals who are already covered under employer-provided insurance. The Act raises the bar for private insurance coverage by outlawing some practices but provides several exemptions for existing plans. Just as counselor licensure laws routinely include provisions to "grandparent in" counselors who have been practicing for several years without having to meet new licensure requirements, the Act "grandfathers in"2 existing health plans - those in operation as of March 23, 2010, the date the law was enacted-exempting them from many of the requirements it places on new health plans.

The Act sets limits on how much a health plan can change before it loses its grandfathered status. Any of the following changes result in a loss of grandfathered status:

- Instituting copayment, deductible, and out-of-pocket limit increases of greater than medical inflation plus 15 percentage points

- Increasing coinsurance rates

- Decreasing existing annual dollar limits on coverage or instituting a new annual limit

- Decreasing employer premium contribution rates by more than 5 percentage points
- Eliminating substantially all covered benefits to diagnose or treat a particular condition

This last prohibition may cause health plans to think twice before dropping mental health or substance abuse treatment benefits in response to requirements set forth in the Mental Health Parity and Addiction Equity Act (MHPAEA), enacted in 2008. This is just one of the ways the new law helps strengthen the MHPAEA, as will be discussed later.

\section{HEALTH INSURANCE PROTECTIONS BEGINNING IN 2010}

PPACA includes many important protections for those who already have private health insurance. Several of these apply to all health plans for plan years beginning on or after September 23, 2010, including both new plans and grandfathered group health plans. These protections include the following:

- A requirement that young adults can stay on their parents' health plan until age 26

- Prohibition of preexisting condition exclusions for children under age 19

- Prohibition on use of lifetime coverage limits

- Prohibition on implementation of a new, or reduction of an existing, annual coverage limit

- Prohibition against rescinding coverage or denying payment based on an error or technical mistake on a customer's application for coverage

- Reporting of medical loss ratios and other financial information and offering of premium rebates to enrollees if the plan does not meet specified medical loss ratios

- Use of uniform plan description documents, so that purchasers can make 'apples-to-apples' comparisons between plans

The requirement that health plans extend dependent coverage to young adults up to age 26 merits some elaboration. Young adults can qualify for such coverage even if they no longer live with the parent(s), are not dependents for tax purposes, are not single, or are no longer students. However, young adults are generally not eligible for coverage through a parent's health plan if they are eligible for coverage from

'The text of the law is available online at http://docs.house.gov/energycommerce/ppacacon.pdf. A short 13-page summary of the law has been produced by the Kaiser Family Foundation, a think tank focusing on health policy issues, at http://www.kff.org/healthreform/upload/8061.pdf. A detailed, section-bysection description of the law is available on the website of the Senate's Democratic Policy Committee at http://dpc.senate.gov/healthreformbill/healthbill96.pdf, and a shorter summary is available at http://dpc.senate.gov/healthreformbill/healthbill95.pdf. The Congressional Research Service has also produced helpful reports on the law, including one focusing on its provisions affecting private health insurance plans, available online at http://opencrs.com/document/R40942/.

2The Act uses the term "grandfathered" instead of "grandparented." 
another employer-sponsored insurance plan. The extension of dependent coverage by itself is projected to extend health insurance coverage to 2.37 million young adults (Employee Benefits Security Administration, 2010).

New health plans (as opposed to grandfathered health plans) starting on or after September 23rd must also meet other requirements, such as:

- covering preventive services with no cost-sharing;

- providing direct access to obstetricians and gynecologists without a referral, providing choice of primary care provider, and allowing pediatricians to be classified as primary care providers;

- covering out-of-network emergency services without higher cost-sharing requirements than in-network emergency services and without prior authorization requirements; and

- providing internal and external appeals processes for insurers' denial of claims.

\section{TEMPORARY “HIGH RISK” INSURANCE POOL AND SMALL-BUSINESS TAX CREDITS}

Two other initiatives designed to increase insurance coverage also begin in 2010, targeting two groups often forced to go without it: those with preexisting conditions and small businesses. Currently, 35 states operate high-risk insurance pools, essentially 'coverage of last resort' for people who cannot get affordable insurance coverage because of their health status. PPACA establishes new ground rules for Preexisting Condition Insurance Plans (PCIPs) regarding covered benefits, premiums, and cost sharing for these high-risk plans and provides $\$ 5$ billion in funding to subsidize their expansion. In order to be eligible, individuals must have a preexisting condition and have been without coverage for a continuous 6-month time period prior to the date of applying for coverage. Enrollees will be transitioned into the new health insurance exchanges that begin operation January 1, 2014. Individuals can apply for coverage in a PCIP plan through the health care website at http://www.healthcare.gov/.

To help small businesses provide coverage for their employees, PPACA establishes tax credits totaling $\$ 40$ billion over the next 10 years, starting this tax year. Businesses with fewer than 25 full-time workers (or the equivalent) and average annual wages of less than $\$ 50,000$ will be eligible for the credits. Those employing 10 or fewer workers earning an average wage of less than $\$ 25,000$ will be eligible for a credit covering $35 \%$ of health insurance premium costs $(25 \%$ for nonprofit organizations), with the credit phasing out for larger businesses with higher average wages, up to the 25 employees $/ \$ 50,000$ average annual wage threshold. Through 2013 , the employer contribution eligible for the tax credit is calculated as the lesser of the employer's actual premium contribution or the total contribution needed to cover the average premium in the small group market in business's area for all its employees. Earlier this year, the Internal Revenue Service (IRS) mailed postcards to more than 4 million small employers and nonprofit organizations notifying them of their potential eligibility for health care tax credit assistance.

\section{1-THE CLASS ACT AND MEDICAL LOSS RATIOS}

Health care advocates, including the late Senator Edward Kennedy and his staff, have been working for years to establish a system of long-term care services and supports. An estimated 10 million Americans need such assistance with life's daily activities, but Medicare, the health care program for the elderly and those with disabilities, covers only shortterm skilled nursing and home health services. Medicaid has become the primary payer of long-term care services, to the tune of more than $\$ 100$ billion a year, or about one third of all Medicaid spending (Gleckman, 2010). Remember, though, that Medicaid is only available for those who areor who become-poor. Long-term care can be catastrophically expensive, with nursing home costs averaging over $\$ 70,000$ a year (Watts, 2009). Americans spend roughly $\$ 200$ billion out of pocket each year on long-term care.

To support the expansion of long-term care insurance coverage and funding, Congress included the "Community Living Assistance Services and Supports Act" (or "CLASS Act") in the new health care law. The CLASS program is a voluntary, not mandatory, program for current workers over age 18. If an employer agrees to participate, employees will be automatically enrolled unless they opt out; individuals can also enroll directly, if their employer does not. Monthly premiums will vary by age; the poorest and youngest will pay as little as $\$ 5$ a month, with the average estimated monthly premium being around $\$ 120$. Individuals must work for 5 years before receiving benefits. In return, the average minimum benefit will be at least $\$ 50$ a day, and, once a health care provider determines care is needed, it will be covered as long as necessary. Benefits will be in cash, making it possible to cover the costs of help provided by friends or family members, home renovations, or whatever other supports are needed. In most places, CLASS benefits will probably not cover the full cost of nursing home care, and individuals may want to purchase private long-term care insurance to increase their security, but, as with Social Security, it provides a basic level of support. The CLASS program will be completely self-funded through premiums.

Also starting in 2011 is a requirement that all health plans-including both new health plans and grandfathered health plans-spend a minimum percentage of their total premium revenue on clinical services and quality improvement activities and provide a rebate to enrollees covering the difference, if any. PPACA sets this percentage, known as 


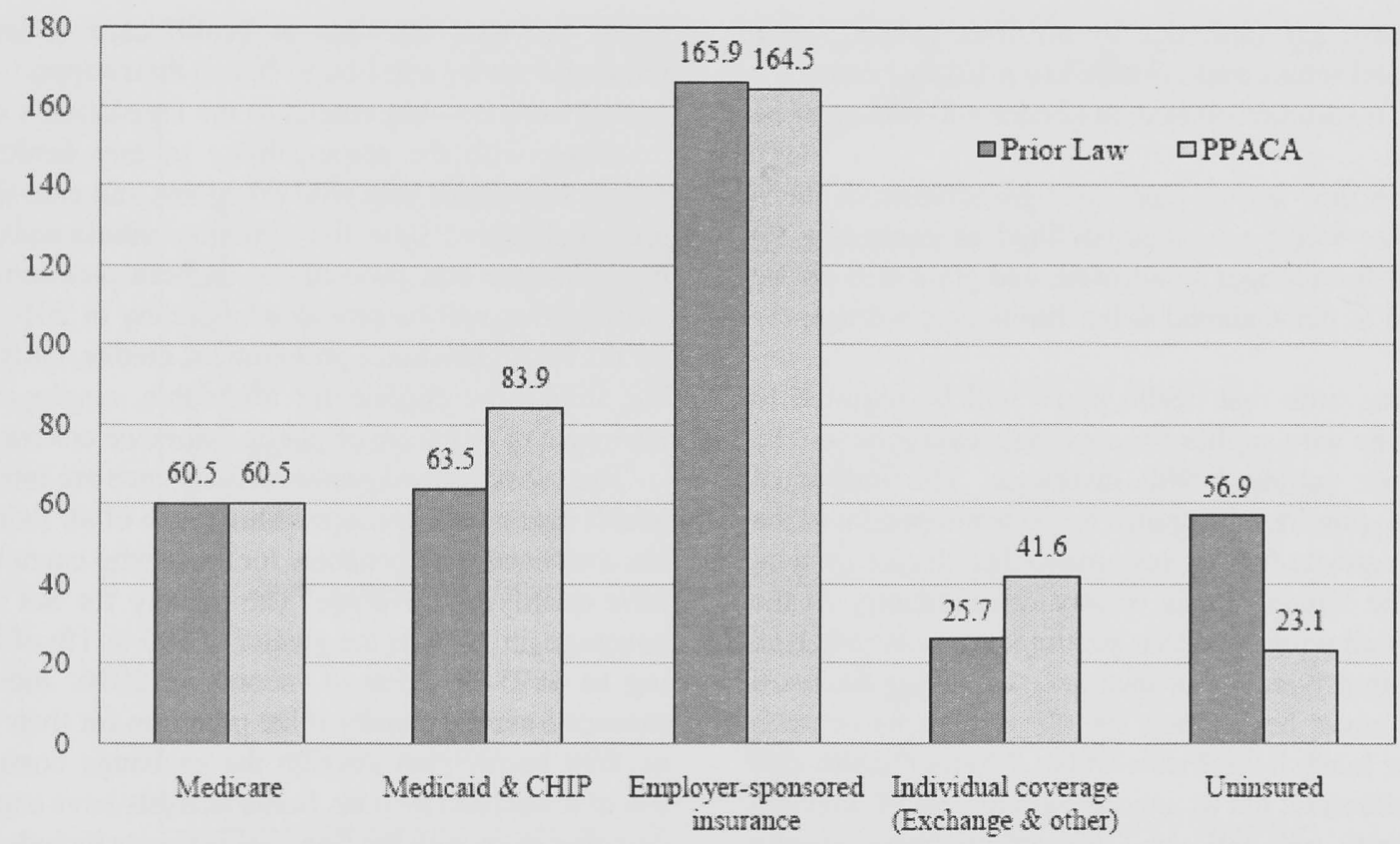

Note: Totals across categories are not meaningful due to overlaps among categories (e.g., Medicare and Medicaid).

From: "Estimated Financial Effects of the 'Patient Protection and Affordable Care Act,' as Amended," by the Centers for Medicare \& Medicaid Services, 2010. Retrieved from https://www.cms.gov/ActuarialStudies/Downloads/PPACA_2010-04-22.pdf

\section{FIGURE 3. Estimated Effect of the Patient Protection and Affordable Care Act on 2019 Enrollment, by Insurance Coverage (in millions)}

the plan's "medical loss ratio," at $85 \%$ for large group plans and $80 \%$ for plans in the small group and individual market, although the Act gives the Secretary of Health and Human Services the authority to adjust the rates. (Large group plans are defined as those covering more than 100 employees, and small group plans are those covering 100 or fewer.) Health plans will be required to report their medical loss ratios annually, and these reports will be made publicly available.

\section{AND BEYOND}

The major building blocks of PPACA take effect in 2014, including the individual mandate to buy insurance, the establishment of state-based insurance exchanges, the beginning of premium credits and cost-sharing subsidies, and a requirement that all but small employers either provide coverage or pay fees. One of the primary ways more individuals would get coverage would be through expansion of the Medicaid program. Under PPACA, through 2013 states have the option to expand Medicaid to cover all nonelderly adults (except for those ineligible based on noncitizenship status) who make up to $133 \%$ of the federal poverty level (FPL). Beginning in 2014, states will be required to extend Medicaid to citizens and certain legal residents under $133 \%$ of the poverty level.
A raft of important private sector insurance requirements begins in 2014. Starting that year, health plans will not be able to deny coverage to anyone based on preexisting conditions, state health insurance exchanges will begin operation, individuals who can afford health insurance will be required to have it, an array of tax credits and cost-sharing reductions will begin to help individuals with their coverage and subsequent expenses, the small business tax credit will be increased, and Medicaid coverage will be expanded.

Beginning in 2014, health insurers in the individual and small group market (except for grandfathered health plans) will have to end many common practices used to avoid covering individuals who might need care:

- Insurers will have to accept every employer and individual applying for coverage and will have to allow renewal of coverage regardless of health status, utilization of health services, or any similar factor.

- Health plans will not be allowed to use preexisting condition exclusions or other types of discrimination based on health status or otherwise discriminate in their coverage based on health status, medical condition, claims experience, genetic information, or the like.

- Health insurance premiums in the individual and small group market may vary only by family structure, 
geography, age (although by no more than a 3 to 1 ratio), and tobacco use (limited to a 1.5 to 1 ratio).

- Premium variations based on gender will no longer be allowed.

- For both new health plans and grandfathered plans, excessive waiting periods (defined as exceeding 90 days) will no longer be allowed, and plans will not be allowed to place annual dollar limits on coverage.

At the same time that health plans will be required to accept everyone who applies for coverage, everyone will be responsible for getting health insurance. The individual requirement to purchase insurance is a key component of the bill. The prerequisite for any sustainable health care system, whether in the United States or any other country in the world, is participation, and that participation can either be through buying private sector insurance or paying the taxes necessary to cover health care spending; there is no such thing as a free lunch hour doctor's visit. Modern health care can be very effective, but as anyone who has spent time in a hospital recently will tell you, this effectiveness usually comes with a high price. The only workable system is to use insurance, as is done with car insurance and home insurance; individuals put a small amount of their money away, pooling resources as a group against the possibility that some of them might have large expenses. Insurance only works if people who ultimately do not use it buy it anyway, and if people buy it before they know they need it.

Just as with car insurance, one person's refusal or inability to buy insurance makes it that much more expensive for those who do. An individual mandate to buy health insurance coverage is a key part of the Massachusetts health care program signed into law by then-Governor Mitt Romney, and a mandate was also included in major health care reform legislation introduced by then-Senator John Chafee (R-RI) and 18 other Republican Senators in 1993, including Bob Dole (S. 1770 from the 103rd Congress). As one analyst has noted, "the Republican counter to the Clinton Plan, sponsored by Republican Senators Bob Dole (R-KS) and John Chafee (RRI), is now known as Obamacare" (Morone, 2010).

On a pragmatic level, an individual mandate to buy insurance was a key political building block that made the legislation possible. Legislators wanted the new health care system to be based on the existing private health insurance, and they wanted it to expand coverage to those left out of the current system. If the health insurance industry was going to be faced with the stick of being prohibited from excluding those with preexisting conditions, from rescinding coverage when beneficiaries needed it, from charging significantly higher rates for those unlucky enough to be born with an illness, and from engaging in similar types of practices, then it also needed the carrot of having millions of new enrollees coming in their doors. Health insurance opposition had killed previous attempts at health care reform (anyone remember Harry and Louise?), and their support-or at least nonopposition-was crucial to the legislation's success.

Along with the responsibility to buy health insurance comes significant help with premiums and cost sharing. Figure 4 and Table 1 show the eligibility criteria and corresponding insurance cost protections, on both premiums and costsharing, that will be provided beginning in 2014. To qualify for the health insurance premium tax credits, individuals must not already be eligible for affordable, employer-sponsored insurance or any form of public insurance coverage.

The subsidies and premium assistance are intended to put health insurance coverage within reach of all individuals and are combined with penalties for those who cannot prove they have qualifying coverage. The penalty for not maintaining coverage, in 2014 , is the greater of $\$ 95$ or $1 \%$ of income, rising to $\$ 695$ or $2.5 \%$ of income in 2016. Individuals are exempt from the penalty if the premium for their state's lowest-cost health plan through the exchange costs more than $8 \%$ of household income. Some analysts have expressed concern that even with the financial supports included in the bill, many people will still be unable to afford coverage (Rabin, 2010). The IRS may try to collect the penalty by reducing future tax refund amounts, but it is important to note that individuals who do not purchase coverage and do not pay the penalty will not be subject to criminal prosecution.

A similar "play or pay" requirement on large employers also begins in 2014. Large employers (defined as those with 50 or more employees) will be required to provide affordable coverage or pay penalties. Coverage is considered "affordable" if premiums do not cost full-time employees more than $9.5 \%$ of their household income. Also in 2014 , the tax credit available to small employers to help them buy coverage will rise from $35 \%$ to $50 \%$ of plan costs (from $25 \%$ to $35 \%$ for nonprofits), for policies purchased through the new health insurance exchanges.

Most individuals and small businesses gaining health insurance as a result of the new law will do so through health insurance exchanges, large state-operated insurance purchasing pools. Ultimately, the exchanges are projected to cover an estimated 24 million Americans-including all members of Congress - by 2019. States will be responsible for setting up insurance exchanges (formally entitled "American Health Benefits Exchanges"), within which health plans meeting criteria established in the law (such plans are referred to as "qualified health plans") can be sold to individuals and small employers. As described by staff with the Congressional Research Service in their report on the new law, "Exchanges will not be insurers, but will provide qualified individuals and small businesses with access to insurers' QHPs [qualified health plans] ... in a similar way, for example, that Travelocity or Expedia are not airlines but provide access to available flights and fares in a comparable way" (Congressional 


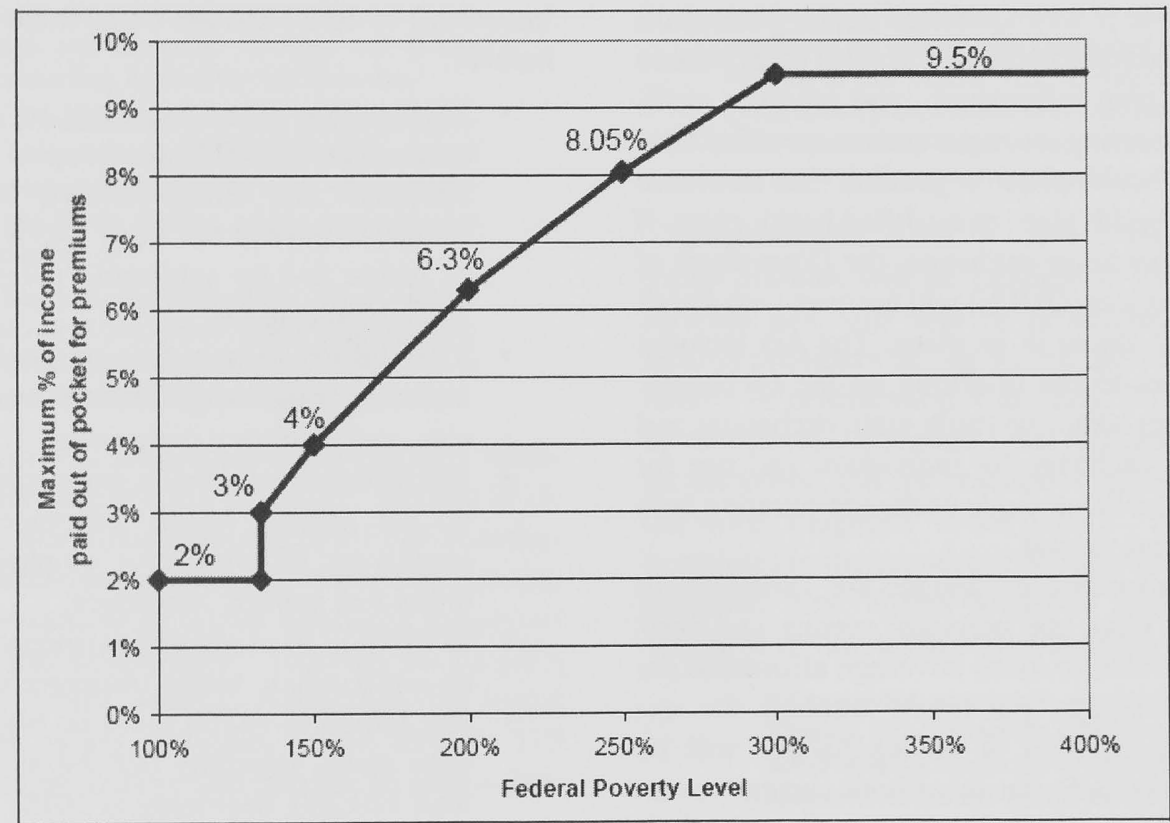

From: Private Health Insurance Provisions in PPACA (P.L. 111-148) (CRS Report R40942, p. 23), by the Congressional Research Service, April 15, 2010, Retrieved from http://bingaman.senate.gov/policy/crs_privhins.pdf

\section{FIGURE 4. Maximum Out-of-Pocket Premiums for Eligible Individuals in 2014 Under PPACA, by Federal Poverty Level (FPL)*}

*Maximum premium percentage based on price of second-lowest cost plan with an actuarial value of $70 \%$ (meaning plan pays, on average, $70 \%$ of the cost of covered benefits). Plans with an actuarial value of $70 \%$ are defined as "silver" benefit plans; "gold" plans have an actuarial value of $80 \%$, "platinum" plans have an actuarial value of $90 \%$, and "bronze" plans have an actuarial value of $60 \%$.

TABLE 1. Cost-Sharing Subsidies in PPACA (2014): Out-of-Pocket Maximums and Average Percentage of Allowed Expenses Paid by Plan, by Income Tier

\begin{tabular}{ccc}
\hline $\begin{array}{c}\text { Federal poverty } \\
\text { level (FPL) }\end{array}$ & $\begin{array}{c}\text { Out-of-pocket limit relative to maximum } \\
\text { permissible for HSA-qualified } \\
\text { high deductible health plans }\end{array}$ & $\begin{array}{c}\text { Percent of allowed } \\
\text { health care expenses } \\
\text { covered by plan }\end{array}$ \\
\hline Up to $150 \%$ & Reduced by twa-thirds & $94 \%$ \\
$151 \%-200 \%$ & Reduced by two-thirds & $87 \%$ \\
$201 \%-250 \%$ & Reduced by one-half & $73 \%$ \\
$251 \%-300 \%$ & Reduced by one-half & $70 \%$ \\
$301 \%-400 \%$ & Reduced by one-third & $70 \%$ \\
\hline
\end{tabular}

Source: PPACA (P.L. III-148. as amended by P.L. III-152).

Notes: In 2010, the out-of-pocket maximum for HSA-qualified HDHPs is $\$ 5.950$ for single coverage and $\$ 11,900$ for family coverage. Thus, a two-thirds reduction in 2010 (although these provisions are not effective until 2014 ) would be an out-of-pocket maximum of $\$ 2.000$ for single coverage and $\$ 4.000$ for family coverage; a one-half reduction would be $\$ 3,000$ and $\$ 6,000$. respectively; and a one-third reduction would be $\$ 4,000$ and $\$ 8.000$, respectively

From: Private Health Insurance Provisions in PPACA (P.L. 111-148) (CRS Report R40942, p. 23), by the Congressional Research Service, April 15, 2010. Retrieved from http://bingaman.senate.gov/policy/crs_privhins.pdf 
Research Service, 2010, p. 18). Qualified health plans must provide the essential benefits package and meet other criteria related to marketing, plan information, and provider availability, in addition to meeting the requirements specified elsewhere in the law for health plans in general. The insurance exchange will certify health plans as qualified health plans. If a state chooses not operate an exchange, the Department of Health and Human Services (DHHS) will contract with a nongovernmental entity to do so in its place. The Act includes grant funding for states to use in setting up the exchanges. States can join together to set up multi-state exchanges and can either set up one exchange for individuals and one for small businesses or establish a single exchange covering both small businesses and individuals.

The state health insurance exchanges are exclusive, in two important ways. First, the premium credits and costsharing subsidies provided to make coverage affordable are available only for coverage purchased through the exchanges. Second, participation in the exchanges will be somewhat limited. Only individuals without current coverage, who need help in purchasing coverage because their employers' coverage takes up a high percentage of their annual income, and small employers will be able to participate in the exchanges. Before 2016, states can define "small employers" as either those with 50 or fewer employees or as those with 100 or fewer employees; in 2016, the bar is raised so that employers with 100 or fewer employees are considered "small." Only in 2017 can states allow large employers to buy coverage through their exchange.

Although it did not address the counseling profession's key issue, PPACA makes important changes in the Medicare program. Most notably, it will slowly close the "donut hole" in prescription drug coverage, under which beneficiaries who pay more than $\$ 2,830$ a year on prescription drugs must pay all subsequent costs completely out of their own pocket, until their annual expenses exceed $\$ 6,440$. Under PPACA, Medicare beneficiaries in the "donut hole" this year have been mailed checks for $\$ 250$ to provide some assistance, and beginning in 2011 seniors who fall into the donut hole will receive a $50 \%$ discount on drugs. This percentage will rise slowly until the donut hole is effectively eliminated in 2020.

Medicare will also begin paying $100 \%$ of the cost of preventive services for beneficiaries, starting January 1, 2011. As discussed below, certain mental health services have been designated "preventive services" for these purposes by the US Preventive Services Task Force.

To pay for itself, the legislation includes a broad package of spending reductions, tax increases, and fees. Over 10 years, the Act will reduce Medicare Advantage payments by $\$ 135.6$ billion, payments for home health care services by $\$ 39.7$ billion, and Disproportionate Share Hospital Payments (which exist to defray the costs to hospitals of providing uncompensated care to individuals without health insurance) by $\$ 22.1$ billion. Other major sources of funding include:

- $\$ 210$ billion in tax increases on individuals making more than $\$ 200,000$ (or couples making more than $\$ 250,000$ and filing jointly), by increasing their Medicare payroll tax from $1.45 \%$ of wages to $2.35 \%$ of wages and by subjecting investment income to a $3.8 \%$ Medicare tax;

- $\$ 107$ billion in new fees on health care companies, including drug companies, medical equipment companies, and insurance companies;

- $\$ 52$ billion from penalty payments by employers who do not provide health insurance coverage to their employees or who have employees qualifying for individual subsidy assistance;

- $\$ 17$ billion from penalty payments by individuals who do not purchase health insurance coverage; and

- $\$ 32$ billion in excise taxes on high-cost health insurance plans, generally defined as those costing more than $\$ 10,200$, beginning in 2018 .

\section{PPACA AND COUNSELORS AS PROVIDERS}

Despite the law's lack of a provision establishing Medicare reimbursement of counselors, the PPACA will have a positive impact on counselors in their role as providers of behavioral health services providers, in a few different ways.

Most notably, Section 5002(b)(2) of the Act amends the Public Health Service Act to establish a definition of "mental health service professional" reading as follows:

The term "mental health service professional" means an indi-
vidual with a graduate or postgraduate degree from an accred-
ited institution of higher education in psychiatry, psychology,
school psychology, behavioral pediatrics, psychiatric nursing,
social work, school social work, substance abuse disorder
prevention and treatment, marriage and family counseling,
school counseling, or professional counseling.

Note that the definition recognizes degrees in both "school counseling" and "professional counseling," as well as in "marriage and family counseling."

Section 5203 of the Act establishes a new health care workforce loan repayment program for pediatric subspecialists and providers of mental and behavioral health services to children and adolescents who are (or will be) working in health professional shortage areas. The section again includes counselors in its definition of eligible professionals:

(B) CHILD AND ADOLESCENT MENTAL AND BEHAVIORAL HEALTH.-For purposes of contracts with respect to child and adolescent mental and behavioral health care, the term "qualified health professional" means a health care professional who-

(i) has received specialized training or clinical experience in child and adolescent mental health in psychiatry, psychology, school psychology, behavioral pediatrics, psychiatric 
nursing, social work, school social work, substance abuse disorder prevention and treatment, marriage and family therapy, school counseling, or professional counseling;

(ii) has a license or certification in a State to practice allopathic medicine, osteopathic medicine, psychology, school psychology, psychiatric nursing, social work, school social work, marriage and family therapy, school counseling, or professional counseling; or

(iii) is a mental health service professional who completed (but not before the end of the calendar year in which this section is enacted) specialized training or clinical experience in child and adolescent mental health described in clause (i).

The Act authorizes $\$ 20$ million for the health care workforce loan program for each of fiscal years 2010 through 2013.

In addition to the workforce loan program, PPACA authorizes mental and behavioral health education and training grants to eligible institutions of higher education to support student recruitment and development. Although the program includes a funding stream focused specifically on social workers and another on psychologists, it also includes $\$ 10$ million in funding for institutions and training programs that:

are establishing or expanding internships or other field placement programs in child and adolescent mental health in psychiatry, psychology, school psychology, behavioral pediatrics, psychiatric nursing, social work, school social work, substance abuse prevention and treatment, marriage and family therapy, school counseling, or professional counseling. (PPACA, Sec. 5306)

\section{Mental Health Parity and Addiction Equity Act (MHPAEA) Strengthened}

The PPACA solidifies the protections for mental health and substance abuse services provided by the Mental Health Parity and Addiction Equity Act (MHPAEA), enacted in 2008. Currently, MHPAEA's requirements do not apply to small group health plans, defined as those covering 50 or fewer employees. However, PPACA requires insurers in the individual and small group markets to cover defined essential benefits starting in 2014. Although the Secretary of Health and Human Services is given the task of defining what is in the essential health benefit package, the law stipulates that it must include "mental health and substance use disorder services, including behavioral health treatment" (PPACA, Sec. 1302(b)(1)(E)).

A separate insurance protection included elsewhere in the Act should help ensure that this results in expanded coverage of counselors' services. PPACA includes a provision (a new Section 2706 of the Public Health Service Act, established by Sec. 1201 of PPACA) that states:

A group health plan and a health insurance issuer offering group or individual health insurance coverage shall not discriminate with respect to participation under the plan or coverage against any health care provider who is acting within the scope of that provider's license or certification under applicable State law. This section shall not require that a group health plan or health insurance issuer contract with any health care provider willing to abide by the terms and conditions for participation established by the plan or issuer. Nothing in this section shall be construed as preventing a group health plan, a health insurance issuer, or the Secretary from establishing varying reimbursement rates based on quality or performance measures. (emphasis added)

Beginning in 2014, insurers in the individual and small group markets will be required to cover behavioral health services and will also be prohibited from discriminating against providers acting within the scope of that provider's license or certification. Currently, 30 states explicitly allow counselors at the highest level of licensure to diagnose mental disorders, and the practice is strongly supported (even if the word "diagnose" is not included in the scope of practice in statute) in the remaining jurisdictions (Lum, 2010). As an example, New York's counselor licensure law defines the "practice of mental health counseling" to include:

a. the evaluation, assessment, amelioration, treatment, modification, or adjustment to a disability, problem, or disorder of behavior, character, development, emotion, personality or relationships by the use of verbal or behavioral methods with individuals, couples, families or groups in private practice, group, or organized settings; and

b. the use of assessment instruments and mental health counseling and psychotherapy to identify, evaluate, and treat dysfunctions and disorders for purposes of providing appropriate mental health counseling services. (New York Consolidated Education Law, Article 163, § 8402, paragraph 1)

\section{Preventive Services Coverage for Depression and Depression Research}

Depression is a significant driver of health care costs, including both direct care costs and increased costs for treatment of comorbid conditions (Katon, 2003), and depression also results in social costs resulting from reduced work productivity and absenteeism (Stewart, Ricci, Chee, Hahn, \& Morganstein, 2003). PPACA requires new health plans to cover preventive services and immunizations without cost sharing. The specific preventive services that must be covered are those having a rating of " $\mathrm{A}$ " or " $\mathrm{B}$ " as evaluated and recommended by the US Preventive Services Task Force (USPSTF). Behavioral health and counseling services are included on the list of such interventions as currently established by USPSTF. The agency currently recommends the provision of the following services:

- screening and behavioral counseling interventions to reduce alcohol misuse by adults, including pregnant women, in primary care settings;

- screening of adolescents (12-18 years of age) for major depressive disorder when systems are in place to ensure accurate diagnosis, psychotherapy (cognitive-behavioral or interpersonal), and follow-up; and

- screening adults for depression when staff-assisted depression care supports are in place to assure accurate diagnosis, effective treatment, and follow-up. (USPSTF, 2010) 
PPACA establishes a competitive grant program for the establishment of National Centers of Excellence for Depression. The Act authorizes $\$ 100$ million a year, for each of fiscal years 2011 through 2015, for the program.

The Act also includes provisions designed to make it easier to care for individuals with disabilities in noninstitutional settings. Under the "Community First Choice Option," contained in Sec. 2401 of the law, states will have the option of covering community-based attendant services and supports through their Medicaid programs for beneficiaries who wanted such services and who would otherwise need to be cared for in a hospital, nursing facility, or intermediate care facility for individuals with developmental disabilities.

\section{MEDICARE COVERAGE OF COUNSELORS- CLOSE, BUT NOT CLOSE ENOUGH}

Medicare is the nation's single largest health insurance program and will remain so in a post-PPACA world. The Act's failure to include language establishing Medicare coverage of medically necessary outpatient mental health care provided by licensed professional counselors is a major disappointment for the profession and a missed opportunity for Congress to improve access to care. Medicare's beneficiary population will balloon steadily with the aging of the baby boom generation, at the same time that many mental health providers will be leaving practice.

According to the $\mathrm{CBO}$, Medicare coverage of the services of licensed professional counselors and marriage and family therapists is projected to cost $\$ 400$ million over 10 years. Since licensed professional counselors outnumber marriage and family therapists by approximately two to one, this means that gaining Medicare recognition would put more than $\$ 250$ million in the pockets of counselors over this time period, or $\$ 25$ million a year, even without counting beneficiary copayments. This would be a tremendous boost to the profession. The American Counseling Association (ACA) has been working for years to gain Medicare recognition for professional counselors, and this time we appeared well positioned for success.

Scores of different Medicare bills are introduced in each Congress, and the challenge for their advocates is getting them on the next legislative train leaving the station. Health care reform promised to be a powerful, powerful train, encompassing billions of dollars in spending, including on Medicare. This would be more than enough to cover the projected cost of our proposal.

An additional cause for optimism was the newly invigorated working relationship between counselor and marriage and family therapist organizations. For the first time, five organizations were working closely together, in concert, to gain the enactment of counselor and marriage and family therapist coverage under Medicare: the ACA, the National
Board for Certified Counselors (NBCC), the American Mental Health Counselors Association (AMHCA), the American Association for Marriage and Family Therapy (AAMFT), and the California Association of Marriage and Family Therapists (CAMFT). Although these organizations have collaborated to some degree in the past, the coalition began working on a new, more intimate level in this Congress, joining together on lobbying visits, sharing information, and developing strategy together.

Things began well in July of 2009 , when Medicare coverage of counselors and of marriage and family therapists was included as Section 1308 of H.R. 3200, the "America's Affordable Health Choices Act of 2009," introduced by Rep. John Dingell (D-MI). Congressman Dingell, for many years the powerful chairman of the House Energy \& Commerce Committee, was chosen to introduce the legislation by his fellow leaders in the chamber because of his longstanding support for health insurance expansion. Congressman Dingell's father, John D. Dingell, Sr., held the same House seat before him and fought for a single-payer health insurance program alongside then-president Franklin Delano Roosevelt in 1935. The younger Dingell, who is the longestserving member of Congress, has introduced a version of his father's national health insurance legislation in each Congress since 1956, more than 50 years ago.

The counselor and marriage and family therapist coverage provision was included in large part as a result of the strong support of Congressman Pete Stark (D-CA), who has been a longstanding champion on expanding access to general medical services and mental health care, as well as on establishing recognition of licensed professional counselors under Medicare. Stark introduced the "Medicare Mental Health Modernization Act" along with the late Senator Paul Wellstone (D-MN), back in 2001 during the 107th Congress. Stark chairs the House Ways \& Means Committee's Subcommittee on Health, making him a key ally on health care issues.

Counselors and marriage and family therapists also had the support of Congressman Bart Gordon (D-TN), a prominent member of the House Energy \& Commerce Committee and the lead sponsor of H.R. 1693, the "Seniors Mental Health Access Improvement Act," our stand-alone bill in the House of Representatives to establish coverage of counselors and marriage and family therapists. Senator Blanche Lincoln (D-AR) sponsored the identical Senate version of this legislation, S. 671. H.R. 1693 and S. 671 would establish Medicare coverage of medically necessary outpatient mental health services provided by licensed professional counselors and marriage and family therapists, at the same reimbursement rates as are paid to clinical social workers for the same services. The legislation would establish coverage of both licensed professional counselors' and marriage and family therapists' services provided in Federally-Qualified Health Centers (FQHCs) and Rural Health Clinics 
(RHCs). It also would exclude counselors' and marriage and family therapists' services from reimbursement to skilled nursing facilities (SNFs) in the prospective payment system for such facilities, allowing both counselors and marriage and family therapists to bill Medicare directly for services provided. Both H.R. 1693 and S. 671 use the term "mental health counselor" and define the term as an individual who possesses a masters or doctoral degree in mental health counseling or a related field, has performed at least 2 years of postdegree supervised practice, and is licensed by the state where practicing.

Upon its introduction, H.R. 3200 was referred to the three House committees with jurisdiction over health carethe Ways \& Means Committee, the Education \& Commerce Committee, and the Education \& Labor Committee-which each "marked up" (amended) the legislation and reported it out by the end of the July. The counselor and marriage and family therapist coverage provision stayed in the legislation and was never threatened by an amendment to remove it.

The counselor-marriage and family therapist coalition next turned its attention to the Senate, where we were similarly hopeful. After all, the Senate had approved the same Medicare coverage language twice before, in both 2003 and 2005, when the chamber was under Republican control. During the summer of 2009, Senate Finance Committee chairman Max Baucus (D-MT) worked for months with both Democratic and Republican members of his committee in an ultimately futile attempt to develop a bill with bipartisan support. Under increasing pressure from both his colleagues in the Senate and the White House to move legislation, Senator Baucus finally began a Finance markup at the end of September.

When a committee considers legislation on a major topic like health care reform, it usually begins with a bill drafted by the chair of the committee, known as a "chairman's mark." Although this legislation does not have a bill number associated with it, it serves as the basis for the committee in deciding what legislation to approve and report out for further consideration by the chamber. After seeing the chairman's mark, committee members decide which amendments they want to offer, and the committee then either rejects or approves the amendments offered. Before the chair releases the mark, he or she will include provisions of importance to members of the committee; if a particular provision is included in the chairwoman's (or chairman's) mark, then it will take passage of an amendment - over the objections of the committee chair - to get it removed. If a provision is not in the chairman's mark, then it will take the adoption of an amendment to get it included.

When Chairman Baucus released his chairman's mark, our coalition was disappointed to discover that, unlike its counterpart in the House, it did not include Medicare coverage of licensed professional counselors and marriage and family therapists. However, we were still confident that our lead sponsor in the Senate, Senator Blanche Lincoln (DAR), would be able to gain its adoption. Both in this Congress and in the 110th Congress (2007-2008), Senator Lincoln has been the lead sponsor of legislation establishing Medicare coverage of licensed professional counselors and marriage and family therapists. Lincoln first became involved in the legislation in 2001, during the 107th Congress, as the lead Democrat on S. 1760, the "Seniors Mental Health Access Improvement Act" (the name has never changed), introduced by the late Senator Craig Thomas (RWY). Senator Lincoln was a longstanding member of the Senate Finance Committee and a key vote on health care reform. Indeed, her support for health care reform was somewhat in question, raising the possibility that she would have increased leverage to ask for inclusion of one or more of her pet provisions.

During consideration of legislation by a congressional committee, members are required to file the amendments they want to offer with the committee's chair. This gives both the chair and the other members of the committee the opportunity to study the amendments before they are offered, debated, and voted upon. Senator Lincoln filed an amendment to include the language from S. 671 in the legislation. The Finance Committee began marking up the legislation, slowly working its way through members' amendments.

Unfortunately, midway through the markup we learned that Senator Lincoln would not be offering our amendment. This was a surprise to our coalition and left us without a champion halfway through the Finance Committee's consideration of the legislation. During committee consideration of legislation, it is routinely the case that amendments that are filed are not actually offered, and this time the counselor and marriage and family therapist Medicare coverage amendment was one of them. Our coalition attempted to find another Senator willing to take the lead in pushing our provision, but we were unsuccessful. By this stage in the legislation's consideration, senators had chosen the specific issues they wanted to focus on during the debate, and senators are usually reluctant to be seen as taking over another senator's issue. The Senate Finance Committee completed its work on October 13, reporting the bill out by a vote of 14 to 9.

Better news arrived soon after this, when the House took up H.R. 3962, an updated health care bill based on the versions approved earlier in the summer by the three committees with jurisdiction. The bill, entitled the "Affordable Health Care for America Act," was introduced by Congressman Dingell on October 29th and retained the counselor and marriage and family therapist coverage provision that had been adopted by both the House Energy \& Commerce Committee and the House Ways \& Means Committee. 
The House passed its legislation on November 7th by a narrow 220-215 vote. When the Senate passed its bill, without Medicare coverage of counselors and marriage and family therapists, on December 24th, our coalition began working to convince conferees on the legislation to adopt the House's provision. House committee staff members were strongly supportive of our provision, and we heard informally that conferees were leaning toward including our provision in the conference version of the legislation being developed. Unfortunately, Scott Brown's election to the Senate on January 19th stopped the conference process in its tracks, and the bill that had already cleared the Senate became the only viable health care bill. Although our coalition lobbied for inclusion of the counselor and marriage and family therapist coverage provision in the relatively small package of amendments to the bill, we were unsuccessful. Within the space of 3 days near the end of March, the House passed the Senate's bill, both chambers approved a modest package of final changes within budget reconciliation legislation, and President Obama signed the combined legislation into law.

\section{ADVOCACY IMPLICATIONS}

It is very disheartening to come so close to achieving Medicare reimbursement and again fall short. Both the House and Senate have passed legislation including Medicare coverage of counselors twice as part of broader legislation. With all of our work and all of the policy reasons for recognizing counselors under the program, why haven't we succeeded?

A possible explanation, based on the history of other mental health professions in establishing recognition, is that it simply is not time yet. As the Institute of Medicine (IOM) noted in its recent report on professional counselors and the TRICARE program:

\begin{abstract}
Counseling has made progress toward recognition as a profession at a rate comparable with that of professionalization efforts in other mental health disciplines, such as psychology. Connecticut became the first state to pass a law licensing psychologists in 1945, and licensing laws for psychologists had been enacted in all 50 states when Missouri passed its law in 1977, 32 years later (Benjamin, 2006). In comparison, the first counselor-licensure bill was passed in Virginia in 1976, and all 50 states had passed licensure bills for counselors by 2009,33 years later. $(2010$, p. 94$)$
\end{abstract}

Psychologists did not gain reimbursement as full-fledged outpatient service providers under Medicare until 1989, 44 years after passage of the profession's first licensure law. Virginia enacted the first counselor licensure law in 1976, 34 years ago. By this measure, we would be on schedule to achieve Medicare reimbursement in 2020!

Such a comparison is cold comfort for counselor advocates who have been working on this issue for years and whose colleagues collectively lose untold thousands of clients or jobs to other mental health professionals with less training and experience. Nevertheless, it is an undeniable fact that the policymaking process moves slowly. As stated by Baumgartner, Berry, Hojnacki, Kimball, and Leech (2009), "Even serious problems affecting small constituencies may face obstacles unrelated to any active opposition to the proposed policy improvement, but simply due to the scarcity of space on the public agenda" (p. 22).

Many counselors view the social work profession as a formidable, highly effective heavyweight in the federal policy arena. The evidence suggests this opinion is inflated. Baumgartner and his colleagues described the difficulties faced by clinical social workers in gaining direct, individual reimbursement under Medicare for services provided in skilled nursing facilities (SNFs) instead of having their services included in payment bundle provided to the nursing facility. In exploring the reasons why clinical social workers were unsuccessful, the authors quoted an unidentified "advocate" as explaining that "it's not easy to explain what clinical social workers do, how they differ from other social workers, and why this bill needs to be passed in two sentences or two minutes-often you don't have any more time than that. There's a huge education problem" (Baumgartner et al., 2009, pp. 70-71). This analysis was of the social work lobby's failed attempt to change Medicare SNF reimbursement policy in the 106th Congress, which was in session in 1999 and 2000. Ten years later, clinical social workers still have not accomplished their goal, as no provision was enacted in PPACA to change their reimbursement within skilled nursing facilities.

\section{THE CONSEQUENCES OF IGNORANCE}

The social workers' repeated failures in pushing for independent reimbursement in SNFs and the psychologists' long road to gaining Medicare coverage provide the general lesson that policy work is hard and takes a long time. More helpful lessons, though, can be learned from the dynamics of the debate in our fight to gain Medicare coverage as part of the health care reform bill.

When the first health care reform bill was introduced in the House of Representatives in 2009, it was immediately subjected to withering attacks. Within days, online bloggers (and tweeters) had disseminated an extensive-and extensively flawed- "analysis" of the legislation (FactCheck.org, 2009). At least one of these consisted merely of a series of tweets highlighting provisions considered to be offensive. Among the claims made in the tweets and blog postings, an example of which is still online at http://blog.flecksoflife. com/2009/07/19/the-hc-monstrosity/, is the statement "Page 489: Government will cover marriage and family therapy. Government intervenes in your marriage." This was the 
extent of the analysis of our issue and was similar in (lack of) depth to the other complaints lodged against the bill. Page 489 of H.R. 3200 included the provision, Section 1308 , establishing Medicare coverage of licensed professional counselors and marriage and family therapists, under the same medical necessity requirements as apply to mental health services when provided by other professionals. Unfortunately, the "putting government between you and your marriage" depiction of the Medicare provision recognizing counselors and marriage and family therapists was echoed by at least one other organization, the Eagle Forum, joining many other mischaracterizations made regarding the legislation by its opponents

In August, after the three House committees with jurisdiction over the legislation had each approved it, representatives were confronted at town hall meetings with protesters driven sufficiently beyond rational discussion that many actually believed the legislation would set up government death panels for senior citizens (Madden, 2009). Others were outraged that their elected officials would support "government intervention" in Medicare, a program completely designed, funded, and controlled by the federal government. Some individuals attending town hall meetings compared President Obama to Adolf Hitler, and compared the effort to expand health insurance coverage to a Nazi plot (CNN, 2009). At least one member of Congress was hung in effigy (Thrush, 2009). Although debate over the health care reform bill had moved swiftly, if depressingly, into the gutter, our coalition remained hopeful that the counselor and marriage and family therapist Medicare provision would survive. To make sure that congressional offices knew the facts, we sent a joint letter to all offices clarifying that Section 1308 of H.R. 3200 "simply allows the Medicare program to reimburse licensed professional counselors and licensed marriage and family therapists for medically necessary mental health benefits already covered by Medicare," and that "the language does not change the current Medicare mental health benefit package nor in any way impact marriages" (Finerfrock, 2009).

In addition to our potential problems in the blogosphere, we were facing a political problem: Senator Blanche Lincoln, the lead sponsor of our legislation in the Senate, was facing a tough reelection campaign. Although she survived a rare primary challenge by Arkansas Lt. Governor Bill Halter on June 8th, polls consistently showed her trailing Arkansas Republican Representative John Boozman by wide margins (Rasmussen Reports, 2010). Lincoln ultimately lost the election to Boozman, gaining only $37.23 \%$ of the vote to Boozman's $57.64 \%$. Analysts attribute this in part to Senator Lincoln's vote for the Senate's health care bill, the Affordable Care Act, in December, as the new health care law is less popular in Arkansas than it is nationally (Rasmussen Reports, 2010). Senator Lincoln later voted against the reconciliation package of amendments to the Act and was quoted earlier in the year as saying she would "fight against any attempts to push through changes" using the reconciliation process (Budoff Brown \& O'Connor, 2010).

The coalition of lobbyists working to establish Medicare reimbursement of counselors and marriage and family therapists has concluded that, given the razor-thin margin of error and the incredibly intense political environment, proponents of health care reform within Congress and the Obama Administration decided they could not afford the time, energy, or budget dollars necessary to include Medicare coverage of licensed professional counselors and marriage and family therapists in the final package. The risks of being forced to deal with yet another "death panel" type of issue simply were not worth it. At the same time, our lead champion in the Senate was under heavy attack for her involvement in the broader health care issue, thus limiting her ability to engage on our issue.

The outcome of the health care reform debate and how it was conducted suggest a few lessons for the counseling profession.

1. It is imperative that counselor-specific issues are viewed by lawmakers as bipartisan. The ACA has consistently framed improving access to counseling services as a bipartisan issue. Our champions in Congress have been balanced nearly equally between Republicans and Democrats. The most recent member of Congress honored with the ACA Federal Legislative Service Award is Congressman Tom Rooney, a freshman Republican from Florida, in recognition of his efforts to gain independent practice authority for licensed professional counselors within the TRICARE program. The two times we have gained Senate passage of Medicare coverage, in 2003 and 2005, our champion in that chamber was Republican Senator Craig Thomas of Wyoming.

In the current case, the broader issue of health care reform became intensely political. Although Medicare coverage of counselors is, of course, a health care issue, there is unlikely to be any future legislative vehicle as sharply political as the first comprehensive health insurance reform legislation in our nation's history. The counseling profession can improve its chances of gaining recognition under Medicare-and of achieving other legislative goals-by minimizing the perception that such goals are either "Democratic" or "Republican."

A failure in this regard is described by Baumgartner and colleagues, and by their interviewees, as contributing to clinical social workers' lack of success in rectifying their SNF reimbursement issue described earlier.

There are times when even relatively small, low-salience issues are burdened by partisan division. This was certainly the case for those advocates trying to change the payment 
rate for clinical social workers. Several advocates seeking change spoke of the challenges they faced because theirs was "not a Republican issue." Specifically, "clinical social workers are very liberal and have no history of working with or contributing to Republicans." (Baumgartner et al., 2009, p. 86)

The counseling profession must continue to work with members of both political parties, enlisting and recognizing members on both sides of the aisle.

2. Further work is needed to educate the public, the media, and policymakers about who counselors are. The blog postings that caused trepidation among policymakers working on health care reform appear to be attributable, at least in part, to a lack of recognition regarding mental health services and the professionals who provide them. The word "counselor" continues to have such varied meanings that both policymakers and members of the general public can be easily confused about, and skeptical of, counseling-related policies. Counselors can help rectify this in their daily lives by taking the time to educate members of their community regarding the profession when the opportunity arises. This can include not just face-to-face discussions among friends or acquaintances, but contacting local newspapers, television stations, or radio stations when counselors encounter inaccurate or misleading information regarding the profession.

If we lived in a world in which everyone knows who counselors are and knows the value of counseling services, misleading blog postings and internet rumors about "government intervening in your marriage" might still be written, but they would be immediately discounted and disregarded.

3. Counselors need to continue advocating for Medicare reimbursement. The job is not done yet. As tired and frustrated as counselor advocates are by this issue, they can take at least some comfort in the fact that the system is frustrating for everybody. Even with all of the policy arguments on our side, it is still extraordinarily difficult to convince members of Congress that out of the hundreds, if not thousands, of issues with which they are faced, ours deserves their time and attention. Research by the Congressional Management Foundation indicates that the work of individual counselors is essential to getting this attention.

As Figure 5 shows, individual contacts are four times as likely to be rated as having "a lot of influence" with a member of Congress as are contacts from professional lobbyists. Members of Congress are absolutely flooded with

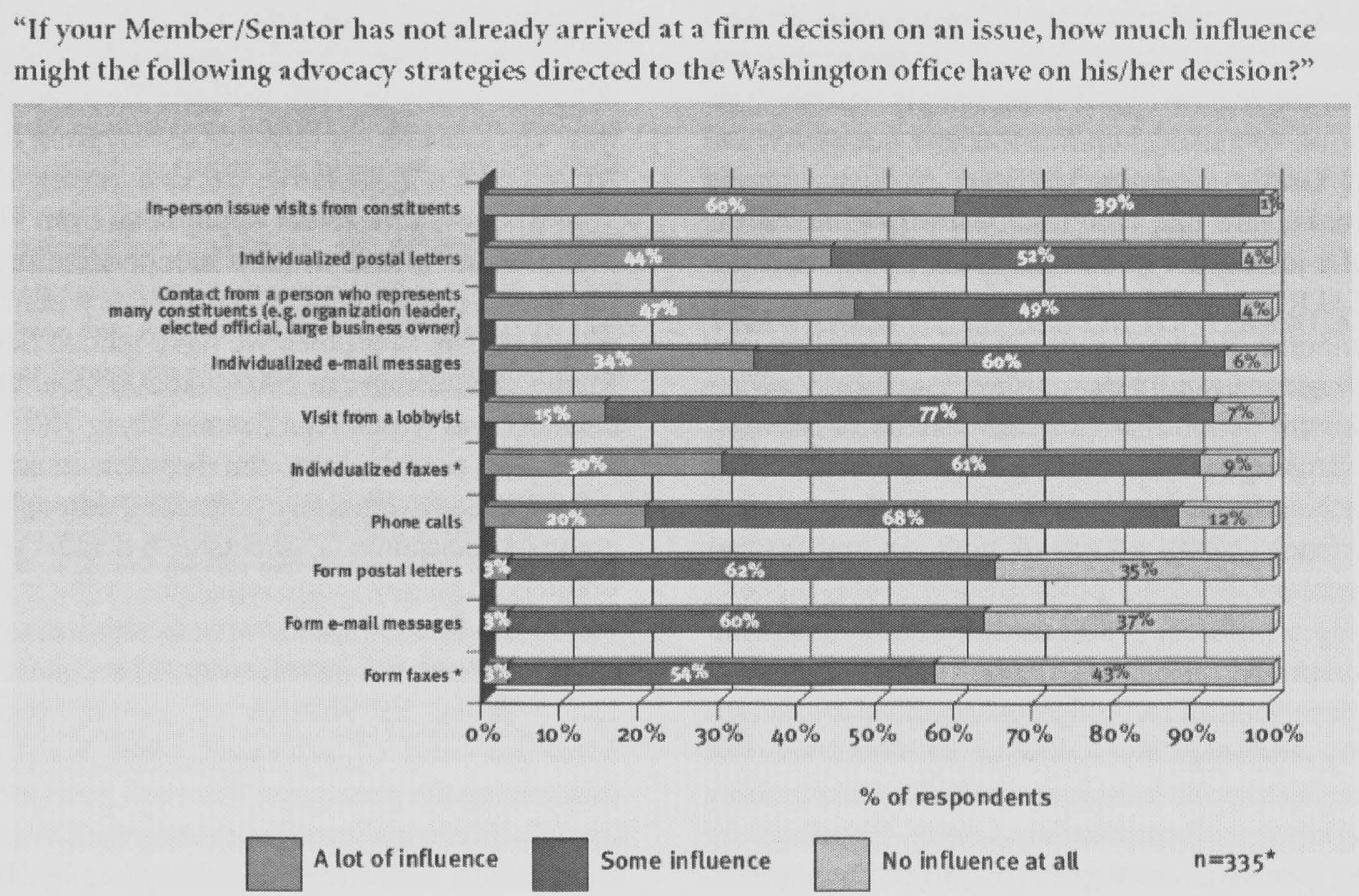

From: Communicating With Congress: How Capitol Hill is Coping with the Surge in Citizen Advocacy, by B. Fitch, and K. Goldschmidt, 2005, Washington, DC: Congressional Management Foundation, p. 30. 
information by lobbyists for every conceivable interest under the sun, and by emails and phone calls generated by lobbying groups and grassroots marketers and contacts from constituents. The only way they can find their way through this overload of data is to prioritize contacts and concerns that are authentic and that come from their constituents. Simply put, the greater the effort shown by the constituent, the closer the legislator is going to listen. Forwarding along a form email takes minimal effort. Taking the time to visit a legislator's office and talk with her or him or a staff member takes more effort-and is much harder to ignore! Without the continued involvement of individual counselors contacting their Senators and their Representative, we will not fight our way onto the congressional radar screen.

\section{Counselors can play a role in trying to elevate our} national political discourse. If the US body politic can be thought of as an individual person, that person is highly conflicted. Counselors are trained to work with clients to help them recognize inner conflicts that are getting in the way of progress and issue resolution and to confront and challenge clients - when necessary-regarding false, counterproductive, or inconsistent beliefs, approaches, and attitudes. With health care policy, our US patient has just achieved a huge breakthrough, but a significant risk of backsliding remains because of an understandably high level of self-doubt.

Change can be scary, and our nation is embarking on a huge national change. The PPACA is our first comprehensive attempt to provide all Americans with decent health insurance coverage. The legislation will undoubtedly need frequent updating and reconfiguration over the years to maximize the effectiveness and reach of health care services while minimizing costs and gaps in coverage. However, the undertaking in which we are now engaged, of taking a chance on something new and leaving behind the proven dysfunction of our existing health care 'system,' must be given a chance to work. On behalf of themselves and their clients, the counseling profession should join the other helping professions in protecting PPACA from baseless attacks and must continue working with policymakers to ensure that counselors are appropriately recognized as service providers.

It is constructive to question the effectiveness of one or more of the Act's provisions and suggest an alternative policy. It is not constructive to deride the legislation as "socialist" and spread misinformation about its provisions and stop there; thus far, no one demanding the repeal of "ObamaCare" has put forward an alternative proposal for ensuring that substantially all Americans have health insurance coverage. There are important conversations that our nation needs to have, not just about our health care system, but also about how to bring down the debt, educate our children, or configure Medicare services. These conversations can be carried out in a serious, sober, considerate, and constructive manner. To make collective decisions through the political system on the basis of appeals to fear, name calling, distrust, the spread of misinformation, and slander inevitably detracts from the quality of those decisions. Such a discourse in one area also decreases the likelihood of our successfully working together on other issues.

The stakes are high. Courtland Lee and Roe Rodgers recently published an article in the Journal of Counseling \& Development entitled "Counselor Advocacy: Affecting Systemic Change in the Public Arena." The article begins:

\begin{abstract}
Deamonte was a 12-year-old student in a public school system in the Washington, DC, metropolitan area. One day he got a toothache. Deamonte's mother, who was a wagereliant worker, had no health insurance, and the family's Medicaid coverage had temporarily lapsed. Because of their situation, she could not afford to pay the $\$ 80$ dentist bill. By the time Deamonte was seen by a dentist, the bacteria from the abscess in his rotting tooth had spread to his brain. After two operations and 6 weeks of hospital care, Deamonte ultimately died. It was later revealed that Deamonte and his younger brother, DaShawn, never received dental attention at any time during their young lives (Otto, 2007).

This case, which received both national and international attention, did not happen in Darfur. It happened in one of the wealthiest regions in the richest country in human history. Deamonte's death underscores an overlooked concern in the debate over universal health coverage - dental care. It is a case of great social injustice, because no child in the United States in the 21 st century should die of a toothache because his or her family cannot afford an $\$ 80$ dentist bill. (Lee \& Rodgers, 2009, p. 284) ${ }^{3}$
\end{abstract}

Lee and Rodgers speak of "the professional and moral responsibility that a counselor has to address the significant social, cultural, and economic challenges that have the potential to negatively affect psychosocial development" (p. 284). To do this and to establish an equal place for themselves in the community of health and social services providers, counselors must become comfortable being legislative advocates. The enactment of the PPACA shows both that significant, positive change is possible, and that more work is needed.

\section{REFERENCES}

Alonso-Zaldivar, R., \& Tompson, T. (2010, September 21). AP poll: Health care law making us muddle-minded. Associated Press. Retrieved from http://news.yahoo.com/s/ap/20100922/ap_on_bi_ ge/us_health_care_poll

The Arc. (2010). The Arc of the United States | Health Care Issues. Retrieved from http://www.thearc.org/page.aspx?pid=2598

Baumgartner, F. R., Berry, J. M., Hojnacki, M., Kimball, D. C., \& Leech, B. L. (2009) Lobbying and policy change: Who wins, who loses, and why. Chicago: University of Chicago Press.

\footnotetext{
${ }^{3}$ The Patient Protection and Affordable Care Act includes pediatric services, including oral and vision care, as essential benefits which health plans must provide to participate in the state health insurance exchanges and also includes provisions to significantly expand Medicaid coverage and simplify the enrollment process.
} 


\section{counseling and Humart Development}

Budoff Brown, C., \& O’Connor, P. (January 27, 2010). Dem impasse on health bill continues. Politico. Retrieved from http://www. politico.com/news/stories/0110/32056.html

Centers for Medicare \& Medicaid Services. (2010, April 22). Memorandum from Chief Actuary Richard S. Foster, entitled "Estimated financial effects of the 'Patient Protection and Affordable Care Act,' as Amended." Retrieved from https://www.cms.gov/Actuar ialStudies/Downloads/PPACA_2010-04-22.pdf

Centers for Medicare and Medicaid Services, Office of the Actuary, National Health Statistics Group. (2010). Relative Contributions to NHE By Source of Funds, 1999 to 2019 (in Billions). Retrieved from http://facts.kff.org/chart.aspx? $\mathrm{ch}=858$

CNN. (2009, August 18). "Barney Frank goes toe to toe at health care town hall." CNN Politics. Retrieved from http://articles.cnn. com/2009-08-18/politics/frank.heath.care_1_health-care-rep-barney-frank-disruption?_s=PM:POLITICS

Congressional Budget Office (CBO). (2009a, November 4). Letter to House Republican Leader John Boehner containing estimate of spending and revenue effects of amendment in the nature of a substitute to H.R. 3962, Affordable Health Care for America Act. Retrieved from http://www.cbo.gov/ftpdocs/107xx/doc10705/hr 3962amendmentBoehner.pdf

Congressional Budget Office (CBO). (2009b, November 6). Letter to the Honorable John D. Dingell containing estimate of spending and revenue effects of H.R. 3962, the Affordable Health Care for America Act, as introduced on October 29, 2009, incorporating the manager's amendment proposed on November 3, 2009. Retrieved from http://www.cbo.gov/ftpdocs/107xx/doc10710/hr3962Dingell _mgr_amendment_update.pdf

Congressional Budget Office (CBO). (2010, March 20). Letter to House Speaker Nancy Pelosi containing estimate of spending and revenue effects of H.R. 3590 and H.R. 4872. Retrieved from http:// www.cbo.gov/ftpdocs/113xx/doc11379/AmendReconProp. pdf

Congressional Research Service. (2010, April 15). Private health insurance provisions in PPACA (P.L. 111-148) (CRS Report R40942). Retrieved from http://bingaman.senate.gov/policy/crs_ privhins.pdf

Employee Benefits Security Administration. (2010, May 13). Group health plans and health insurance issuers relating to dependent coverage of children to age 26, etc. Federal Register, Vol. 75, No. 92. 2010, pp. 27122-27140.

FactCheck.org. (2009, August 28). Twenty-six lies About H.R. 3200. Retrieved from http://www.factcheck.org/2009/08/twenty-sixlies-about-hr-3200/

Finerfrock, W. (2009, August 14). Unpublished email message sent to members of Congress regarding Section 1308 of H.R. 3200, America's Affordable Health Choices Act, on behalf of the American Association for Marriage and Family Therapy, the American Counseling Association, the American Mental Health Counselors Association, the California Association of Marriage and Family Therapists, and the National Board for Certified Counselors.

Fitch, B., \& Goldschmidt, K. (2005) Communicating with Congress: How Capitol Hill is coping with the surge in citizen advocacy. Washington, DC: Congressional Management Foundation,

Gleckman, H. (2010). "Long-term care: A new national option" in Landmark: The Inside Story of America's New Health-Care Law and What It Means for Us All. New York: Public Affairs.

Hooper, M. K. (2010, March 21). Boehner to GOP lawmakers: 'Behave like grown-ups' if healthcare bill is passed. The Hill. Retrieved from http://thehill.com/blogs/blog-briefing-room/news/ 88155-boehner-to-gop-lawmakers-behave-like-grown-ups
Institute of Medicine (IOM). (2010). Provision of mental health counseling services under TRICARE. Washington, DC: The National Academies Press.

Katon, W. J. (2003). Clinical and health services relationships between major depression, depressive symptoms, and general medical illness. Biological Psychiatry, 54, 216-226.

Lee, C., \& Rodgers, R. (2009, Summer). Counselor advocacy: Affecting systemic change in the public arena. Journal of Counseling \& Development, 87, 284-287.

Leonhardt, D. (2010, March 23) In health bill, Obama attacks wealth inequality. New York Times, Retrieved from http://www.nytimes. $\mathrm{com} / 2010 / 03 / 24 /$ business/24leonhardt.html?adxnnl=1 \& $\mathrm{r}$ ef=inco me_inequality\&adxnnlx =1280883661-PDJtd95C\%20MIS7kZSk FtNsA\&pagewanted=print

Lum, C. (2010). Licensure requirements for professional counselors. Alexandria, VA: American Counseling Association.

Madden, M. (August 6, 2009). Obama wants to kill your grandma: Five right-wing myths about healthcare reform, and the facts. Salon.com. Retrieved from http://www.salon.com/news/feature/ 2009/08/06/healthcare

Morone, J. A. (2010) Presidents and health reform: From Franklin D. Roosevelt to Barack Obama. Health Affairs, 29, 1096-1100.

Nasaw, D. (March 25, 2010). Democrats face death threats and vandalism over healthcare reform bill. The Guardian. Retrieved from http://www.guardian.co.uk/world/2010/mar/25/violence-congress -health-reform-republican-obama

Oberlander, J. (2010) Long time coming: Why health reform finally passed. Health Affairs, 29(6), 1112-1116.

Rabin, R. C. (April 19, 2010). Benefit for uninsured may still pose hurdle. New York Times. Retrieved from http://www.nytimes.com/ 2010/04/20/health/20landscape.html?ref=health_care_reform

Rasmussen Reports. (2010). Retrieved from http://www.rasmussenre ports.com/public_content/politics/elections/election_2010/electio n_2010_senate_elections/arkansas/election_2010_arkansas_senate

Rodgers, M. (2010, March 21). Congressional Record, p. H1887

Sahadi, J. (2010) Health reform: The \$\$ story. CNNMoney.Com. March 25, 2010. Retrieved from http://money.cnn.com/2010/03/ 20/news/economy/cbo_reconciliation/index.htm

Scherz, H. (2010, September 1) Dear Patients: Vote to repeal Obama Care. Wall Street Journal, p. A15.

Skocpol, T. (2010) The political challenges that may undermine health reform. Health Affairs, 29, 1288-1292.

Smith, B. (2009, July 17). Health reform foes plan Obama's "Waterloo." Politico. Retrieved from http://www.politico.com/blogs/ben smith/0709/Health_reform_foes_plan_Obamas_Waterloo.html

Stewart, W. F., Ricci, J. A., Chee, E., Hahn, S., \& Morganstein, D. (2003). Cost of lost productive work time among US workers with depression. Journal of the American Medical Association, 289 (23), 3135-3144.

Thrush, G. (July 28, 2009). Rep. Kratovil hung in effigy by health care protester. Politico.com. Retrieved from http://www.politico.com/ blogs/glennthrush/0709/Rep_Kratovil_hung_in_effigy_by_health _care_protester_.html

US Preventive Services Task Force. (2010). USPSTF A and B Recommendations. Retrieved from http://www.uspreventiveservicestask force.org/uspstf/uspsabrecs.htm

Watts, M. O. (2009, October). The community living assistance services and supports (CLASS) act. Kaiser Family Foundation. Retrieved from http://www.kff.org/healthreform/upload/7996.pdf

Wilper, A.P. et al. (2009) Health insurance and mortality in US adults American Journal of Public Health, 99, 2289-2295. 